\title{
Ensino da notação alfabética e práticas de leitura e escrita na educação infantil: uma análise das três versões da Base Nacional Comum Curricular*
}

\author{
Artur Gomes de Morais' \\ Alexsandro da Silval (1) \\ Gabryella Silva do Nascimentol (D)
}

\section{RESUMO}

Neste artigo analisamos o que se prescreveu nas três versões da Base Nacional Comum Curricular $(2015,2016,2017)$ sobre o ensino da notação alfabética e de leitura e produção de textos na educação infantil. Recorrendo à análise documental e à análise temática de conteúdo, examinamos os três documentos categorizando tanto o que apresentavam sobre o ensino da escrita alfabética (escrita espontânea de palavras, promoção da consciência fonológica e conhecimentos de letras) como as prescrições relativas à leitura e compreensão de textos e à produção de textos escritos (gêneros textuais, modalidades e habilidades de leitura e escrita sugeridos). Constatamos que, em todas as versões, a Base Nacional Comum Curricular pouco explicitou o direito de as crianças avançarem em sua compreensão da escrita alfabética antes de ingressarem no ensino fundamental. $\mathrm{Na}$ última versão, as indicações de práticas de leitura de textos predominavam, mas continuaram sendo tímidas as propostas de iniciação à produção de textos escritos.

PALAVRAS-CHAVE

educação infantil; alfabetização; currículo.

*A pesquisa que deu origem a este artigo foi realizada com o apoio do Conselho Nacional de Desenvolvimento Científico e Tecnológico (CNPq).

'Universidade Federal de Pernambuco, Recife, PE, Brasil. 


\title{
TEACHING OF ALPHABETIC WRITING AND PRACTICES OF READING AND WRITING TEXTS IN CHILDHOOD EDUCATION: AN ANALYSIS OF THE THREE VERSIONS OF NATIONAL COMMON CURRICULAR BASE
}

\begin{abstract}
In this article we analyzed the prescriptions appearing in the three versions of Brazilian National Curricular Proposal (Base Nacional Comum Curricular) (2015, 2016,2017) concerning the teaching of alphabetic writing and about reading and writing texts in childhood education. Using documental and content analysis, the three documents were examined, considering what they presented about the teaching of alphabetic writing (invented spelling, phonological awareness, letter knowledge) and also about writing and reading texts (genders suggested, reading comprehension and writing skills to be developed). We found out, in all versions of Brazilian National Curricular Proposal, little explicitation about children's right to advance in their comprehension of alphabetic writing before primary school. In the last version, prescriptions about practices of reading texts were more evident but those about text writing were still scarce.
\end{abstract}

KEYWORDS

childhood education; reading instruction; curriculum.

\section{ENSEÑNANZA DE LA NOTACIÓN ALFABÉTICA Y LAS PRÁCTICAS DE LECTURA Y ESCRITURA DE TEXTOS EN LA EDUCACIÓN INFANTIL: UN ANÁLISIS DE LAS TRES VERSIONES DE BASE NACIONAL CURRICULAR DE BRASIL}

\section{RESUMEN}

En este artículo analizamos qué fue prescrito en las tres versiones de la Base $\mathrm{Na}$ cional Curricular de Brasil (Base Nacional Comum Curricular) (2015, 2016, 2017) sobre la enseñanza de la notación alfabética y de la lectura y escritura de textos en la educación infantil. Usando análisis documental y de contenido, investigamos los tres documentos, categorizando tanto lo que presentaban sobre la enseñanza de la escritura alfabética (escritura espontánea de palabras, consciencia fonológica y conocimiento de letras) como las prescripciones volcadas a la lectura y escritura de textos escritos (géneros textuales, modalidades y habilidades de lectura y escritura de textos). Se constató, en todas las versiones, que Base Nacional Curricular de Brasil ha sido poco explícita sobre el derecho de los niños a avanzar en su comprensión de la escritura alfabética antes de entrar en la escuela primaria. En la última versión, predominaban las prescripciones sobre lectura de textos, pero poco había respecto la escritura de textos.

PALABRAS CLAVE

educación infantil; alfabetización; currículum. 


\section{INTRODUÇÃO}

Que direitos de aprendizagem terão as crianças menores de 6 anos para na escola, durante a educação infantil, começarem formalmente a compreender a notação alfabética e a vivenciarem práticas de leitura e compreensão de textos e de produção de textos escritos, segundo a Base Nacional Comum Curricular (BNCC)? Essa pergunta, que orientou a investigação descrita neste artigo, parte do pressuposto de que vivemos em uma sociedade na qual a escrita está intensamente presente em nosso cotidiano, inclusive no das crianças. Apesar desse "grafocentrismo", vemos que anualmente milhões de crianças de meio popular concluem o ciclo de alfabetização sem conseguir ler e escrever com autonomia, enquanto os filhos das classes médias não vivem tal drama.

De caráter normativo, a BNCC define um conjunto progressivo de aprendizagens consideradas essenciais, que todos os alunos deveriam desenvolver ao longo das etapas e modalidades da educação básica, de modo que tivessem assegurados seus direitos de aprendizagem e desenvolvimento, supostamente em conformidade com o previsto na Constituição de 1988, na Lei de Diretrizes e Bases da Educação Nacional (LDB) de 1996 e no Plano Nacional de Educação (PNE) de 2014.

A argumentação que desenvolveremos começará elencando as razões que nos levam a defender a existência de propostas curriculares em todos os níveis - municipal, estadual, nacional - e as críticas que fazemos ao autoritarismo que, via de regra, caracteriza a imposição desses documentos curriculares, tal como ocorreu com a recente BNCC. Em seguida, criticaremos a opção dos documentos que regulam a educação infantil no Brasil de não privilegiarem a língua escrita e sua notação nessa etapa e apresentaremos nossa posição no que se refere a esse aspecto. Depois de apresentar a metodologia adotada na pesquisa que realizamos, analisaremos, em cada versão, o que prescrevem sobre o ensino da notação alfabética e sobre as práticas de leitura e compreensão de textos e produção de textos escritos, na educação infantil. Ao final, teceremos algumas considerações sobre as implicações da BNCC no currículo vivido da educação infantil no que se refere aos eixos didáticos ligados à língua escrita e a sua notação.

\section{POR QUE DEFENDEMOS A PROPOSIÇÃO DE CURRÍCULOS?}

Currículo é um termo polissêmico (Leite, 2013), e por isso mesmo não é tarefa simples defini-lo (Lopes e Macedo, 2011). Essas últimas autoras até mesmo assumem que não é possível conceituar currículo tomando como base algo que lhe seria intrínseco, mas, tão somente, pode-se chegar a acordos, sempre parciais e situados, sobre os sentidos em torno desse termo. Há, porém, segundo essas pesquisadoras, um aspecto comum no que vem sendo chamado de currículo: "a ideia de organização, prévia ou não, de experiências/situações de aprendizagem realizada por docentes/redes de ensino de forma a levar a cabo um processo educativo" (Lopes e Macedo, 2011, p. 19).

Essa "definição" comporta pelo menos dois aspectos principais, que parecem constituir consenso no campo da teoria curricular. O primeiro deles é o de 
que o currículo corresponde a uma seleção operada no interior da cultura de uma sociedade, realizada sempre com base em um conjunto maior de possibilidades (Forquin, 1993). Essas escolhas representam os saberes que seriam considerados legítimos - não sem tensões e conflitos - para constituírem, em determinado tempo e espaço, o currículo escolar, refletindo, assim, os interesses hegemônicos de determinados grupos. O segundo aspecto refere-se à noção de que o currículo não se limita ao documento formal proposto pelas redes de ensino com a prescrição do que deveria ser ensinado nas escolas, pois inclui também o vivido no cotidiano escolar, o que alguns chamam de "currículo vivido" ou "currículo em ação". Desse modo, "o currículo corresponde ao projeto global de formação escolar, entendido como plano e ação" (Leite, 2013, p. 199).

Neste artigo, analisaremos o "currículo" em seu sentido restrito, isto é, o de documento curricular prescrito às escolas pelas instâncias oficiais, mas sem desconsiderar as interfaces desse documento com o currículo praticado nas instituições escolares. Vivemos em um país em que a maioria daqueles que fazem as universidades públicas são avessos à ideia de documentos curriculares que definam o que cada criança, adolescente ou jovem têm direito de aprender durante a educação básica. Desde o século passado, contudo, Morais (1997) tinha uma posição favorável à existência de propostas curriculares e, tal como ele, acreditamos, hoje, que tais documentos reguladores são fundamentais, embora não operem milagres sozinhos.

A ausência de documentos curriculares colabora para que o que se ensina a alunos de um mesmo ano em uma mesma rede pública ou até numa mesma escola varie aleatoriamente. Em uma pesquisa sobre o ensino de compreensão de leitura no segundo ano do ensino fundamental, Morais, Leal e Pessoa (2013) acompanharam, durante um ano, as práticas de doze docentes de três municípios da região metropolitana de Recife, Pernambuco. Embora todas as escolas participantes tivessem se destacado quanto ao Índice de Desenvolvimento da Educação Básica (IDEB) alcançado no ano anterior, constataram que variavam muito as práticas de ensino em um mesmo estabelecimento escolar e, ao final do segundo ano, as crianças, em nenhum momento das observações, haviam vivenciado a leitura silenciosa e pouco praticavam as estratégias de leitura avaliadas pela Provinha Brasil. Obviamente, teriam muita dificuldade em responder às questões de compreensão leitora que aparecem nesse exame.

Isso nos remete à segunda razão por que somos favoráveis à negociação de propostas curriculares: a falta de progressão das aprendizagens que a ausência de propostas curriculares favorece. Algumas pesquisas (por exemplo, Cruz e Albuquerque, 2011; Oliveira, 2010) constataram que o que os alunos aprendiam no terceiro ano do ensino fundamental não diferia, significativamente, do que se lhes ensinava no primeiro ano, e, às vezes, os alunos de primeiro ano produziam melhores textos escritos que seus colegas que já estavam cursando o terceiro ano do ciclo de alfabetização.

Uma terceira razão relaciona-se à definição do currículo, no Brasil, pelas avaliações externas, conforme denunciado por Soares (2012) há alguns anos. Em nosso país, as avaliações de larga escala sempre foram aplicadas, nacionalmente, sem que os professores tivessem conhecimento do que se esperava que eles ensinassem 
a seus alunos, o que impulsionou as matrizes de habilidades avaliadas em cada exame a tornarem-se, muitas vezes, a referência do que ensinar. Essa esquizofrenia esconde outro dado: essas matrizes (da Provinha ao Exame Nacional do Ensino Médio - ENEM) nunca foram debatidas publicamente e, por inércia, continuam sendo mantidas sem reformulações desde que o Instituto Nacional de Estudos e Pesquisas Educacionais Anísio Teixeira (INEP), anos atrás, atribuiu a algum pequeno grupo de acadêmicos não só o poder de ditar o que deveria ser avaliado, mas também de definir como tais avaliações deveriam apresentar-se.

Além das avaliações externas, os "sistemas"e "apostilados" de ensino também têm ocupado o lugar de currículo em nosso país. Com a invasão e crescimento de grupos privados que vendem seus "pacotes", que têm sido adotados, cada vez mais, por muitas redes públicas de ensino, e isso desde a educação infantil, vemos outra tragédia acontecer: na ausência de propostas curriculares próprias das redes públicas - e às vezes a despeito delas -, são os mercadores da educação que também passam a ditar o que se ensina e se avalia, de forma padronizada, de norte a sul do país. Esses sistemas e apostilados têm também se associado aos sistemas de avaliação externa, ofertando às escolas e redes de ensino serviços de "melhoria dos resultados nessas avaliações".

Mas, usamos aqui a expressão negociar propostas curriculares. E o fizemos porque nos parece absolutamente inaceitável a forma autoritária como tais documentos são muitas vezes elaborados. Via de regra, os educadores são excluídos do processo e algum pequeno grupo é que redige o texto curricular a ser adotado por toda uma rede de ensino. Esse foi o caso da última versão da BNCC, imposta pelo Ministério da Educação (MEC) no final de 2017. Aprovada por um Conselho Nacional de Educação (CNE) desfigurado, depois do golpe que destituiu a presidenta Dilma Rousseff, a BNCC imposta traz elementos que não apareciam nas versões anteriores e que nunca foram debatidos publicamente.

Conforme salientado por Aguiar (2018), as três versões da BNCC refletem, por um lado, os embates entre os vários atores envolvidos no processo de elaboração do documento e, por outro, as repercussões das mudanças no contexto político brasileiro no campo da educação. Com relação ao primeiro aspecto, a autora supracitada chama atenção para a influência de institutos e fundações privadas, responsáveis pela comercialização dos já mencionados "apostilados" e "sistemas de ensino", que participaram, direta ou indiretamente, da construção do documento. Já com relação ao segundo aspecto, Aguiar (2018) salienta que o processo de elaboração da BNCC sofreu um deslocamento, em sua terceira versão, em virtude de mudanças no MEC, decorrentes do impeachment da presidenta Dilma Rousseff. Nesse contexto, foi instituído o Comitê Gestor da Base Nacional Comum e Reforma do Ensino Médio, que se institui como instância responsável pela sistematização da terceira versão da BNCC, que foi enviada ao CNE e imposta em 2017, contrariando o movimento de discussão anterior.

A história tem mostrado que, quando educadores e outros atores sociais são excluídos desse tipo de processo, a tendência é não aderirem às prescrições impostas e criarem táticas (Certeau, 1994) de resistência ante a norma autoritária. No atual caso brasileiro, grupos privados começam a vender serviços de assessoria para "en- 
sinar", por exemplo, como se deve avaliar conforme a BNCC e outras mercadorias afins. Conhecer minuciosamente o que esse documento prescreveu, em suas três versões, para o ensino de língua escrita e sua notação na educação infantil parece-nos, então, fundamental para assumirmos um posicionamento sobre o que fazer em nossas escolas, naquela etapa de ensino.

\section{O ENSINO DA LÍNGUA ESCRITA E DE SUA NOTAÇÃO NO CURRÍCULO DA EDUCAÇÃO INFANTIL NO BRASIL: CRÍTICAS E POSICIONAMENTOS}

A atenção especial que dedicaremos ao que a BNCC propôs como currículo para a educação infantil tem justificativas que nos parece relevante explicitar. Julgamos extremamente preocupante a coexistência dos sistemas "casa grande e senzala" de ensino (Morais, 2012) em nosso país, com os quais passamos a naturalizar e a não discutir a grande diferença de oportunidades vividas pelos filhos das classes médias, frequentadoras das redes privadas de ensino, e seus pares das camadas populares, que constituem a maioria da população e estão nas salas de aula das escolas públicas.

Para as crianças pequenas, até pouquíssimos anos esse apartheid educacional existia, mesmo do ponto de vista legal, quando não se assegurava o direito de todas elas, com 4 e 5 anos, a terem vagas na educação infantil e só se garantia seu acesso ao ensino fundamental aos 7 anos. A ampliação do ensino fundamental para nove anos, instituída pela lei n. 11.274, de 6 de fevereiro de 2006, que garantiu a inclusão das crianças de 6 anos na escolarização obrigatória na época, encontrou, todavia, resistência por parte daqueles que consideravam um "dano à infância" matricular no ensino fundamental os meninos e as meninas que até então integravam a educação infantil. Posteriormente, com a lei n. 12.796/2013, o direito à educação estendeu-se a todas as crianças de 4 e 5 anos, o que para alguns representaria um processo de "escolarização" da educação infantil, com toda conotação negativa que erroneamente muitos atribuem a esse termo.

Recordemos, ademais, que com a resolução n. 1 do CNE, de 14 de janeiro de 2010, apenas as crianças que completam 6 anos antes do dia $1^{\circ}$ de abril de cada ano letivo podem ingressar no ensino fundamental, regra que há pouco tempo foi mantida por decisão do Supremo Tribunal Federal, que unificou o corte etário para todos os sistemas de ensino do país. Cabe não esquecer que em países como França e Espanha as crianças iniciam o ensino fundamental e o aprendizado formal da leitura e da escrita aos 6 anos. Essa era a vivência dos alunos do sistema "casa-grande" de ensino no Brasil, já que a maioria dos filhos das classes médias iniciava o ensino fundamental quando completavam 6 anos, quer tivessem nascido antes de $1^{\circ}$ de abril ou depois!

Porém, é preciso não apenas cedo garantir o acesso das crianças à escola e ampliar o seu tempo de permanência nessa instituição. É necessário também assegurar a qualidade da experiência escolar vivenciada por meninas e meninos, tendo em vista que, há algumas décadas, diferentes estudos, realizados em variados 
países, têm atestado que o acesso à educação infantil contribui para a redução do fracasso escolar e a qualidade dessa experiência escolar é condição fundamental para a diminuição do fracasso das crianças na alfabetização, especialmente no caso de crianças mais pobres. Campos et al. (2011), em estudo que teve como objetivos avaliar a qualidade da educação infantil em seis capitais brasileiras e examinar o impacto dessa qualidade nos resultados de aprendizagem apresentados por alunos do segundo ano do ensino fundamental, constataram que a frequência a escolas de educação infantil de boa qualidade contribuía positivamente no desempenho dos alunos na Provinha Brasil, no segundo ano do ensino fundamental.

A observação e a comparação dos conhecimentos revelados por crianças de diferentes grupos socioculturais, ao final da educação infantil, alerta-nos para a urgência de lutarmos contra as consequências negativas de propostas pedagógicas que, em nome do respeito à infância, defendem ardorosamente que na educação infantil os verbos "ensinar" e "aprender" estejam proscritos e que também esteja proibido definir "conteúdos" de ensino e aprendizagem, sob o argumento de que isso privaria as crianças das interações e brincadeiras. Em nosso entender, na prática tais propostas se prestam para manter o apartheid entre meninos e meninas pobres e seus pares de classe média.

A posição que defendemos neste artigo não é, todavia, a de antecipar o ensino sistemático da escrita alfabética para a educação infantil. Essa perspectiva, que Brandão e Leal (2010) designaram como "obrigação da alfabetização", contempla inicialmente um "período preparatório", no qual as crianças são treinadas em antigas "habilidades de prontidão" para a alfabetização (coordenação motora e de discriminação visual e auditiva), consideradas supostos pré-requisitos para aprender a ler e a escrever. Posteriormente, quando então consideradas "prontas" para serem alfabetizadas, são submetidas a um ensino exaustivo e repetitivo de letras e "famílias silábicas" ou relações grafema-fonema.

No entanto, encontramos uma posição, igualmente radical, que as autoras denominaram como "letramento sem letras". Nesse caso, são privilegiadas as outras linguagens (corporal, musical, gráfica, plástica etc.), em detrimento da linguagem escrita. No cenário brasileiro, observamos atualmente uma variação dessa posição, na qual situações vinculadas ao letramento, como a escuta da leitura de histórias e a produção de textos coletivos, são aceitas e defendidas, enquanto aquelas que se referem à exploração de palavras e de suas semelhanças sonoras e gráficas são proibidas. Brandão e Silva (2017) também detectaram uma variação dessa perspectiva, que chamaram de "à deriva...": a curiosidade das crianças sobre a escrita é acolhida, mas não são propostas atividades voltadas à exploração das palavras.

A perspectiva que defendemos neste artigo não se vincula a nenhuma das anteriores, pois consideramos, assim como também propõem Soares (2009) e Brandão e Leal (2010), que, desde a educação infantil, as crianças têm direito a ampliar seus conhecimentos sobre a linguagem escrita e seus usos e funções, escutando a leitura de histórias e de outros gêneros textuais, além de produzirem textos também de gêneros diversos, tendo o professor como escriba, ao mesmo tempo em que brincam com as palavras e refletem sobre elas. É importante ressaltar que, com isso, não se 
pretende minimizar o espaço da brincadeira e da exploração de múltiplas linguagens e, menos ainda, obrigar as crianças a serem alfabetizadas antes dos 6 anos.

Os documentos curriculares nacionais anteriores à $\mathrm{BNCC}$, que de algum modo regulavam a educação infantil, tendiam a não considerar a língua escrita e sua notação como objeto de ensino privilegiado nessa etapa da educação básica. $\mathrm{O}$ Referencial Curricular Nacional para a Educação Infantil (RCNEI) (Brasil, 1998), que contemplava a educação de crianças até os 6 anos, definia, para a faixa etária de 4 a 6 anos, objetivos relacionados quase que exclusivamente ao eixo do letramento, contemplando apenas a familiarização com a escrita, por meio do manuseio de livros, revistas e outros portadores textuais e da vivência de situações de uso desses portadores; escuta de textos lidos pelo professor; interesse pela escrita de palavras e textos, ainda que não convencionalmente; reconhecimento do nome próprio; e escolha de livros para leitura e apreciação.

As Diretrizes Curriculares Nacionais para a Educação Infantil (DCNEI) (Brasil, 2009), promulgadas mais de dez anos depois, assumiam essa mesma perspectiva, ao revelar uma completa "diluição" da escrita em meio às demais linguagens, demonstrando, como também observaram Brandão e Leal (2013), uma intenção explícita de não orientar um trabalho pedagógico voltado à reflexão sobre a notação escrita da língua. Em vez disso, o documento restringia-se a prescrever, de modo muito geral, que as propostas curriculares dessa etapa deveriam ter como eixos norteadores as interações e a brincadeira, garantindo experiências que, entre outras coisas, "[...] possibilitem às crianças experiências de narrativas, de apreciação e interação com a linguagem oral e escrita, e convívio com diferentes suportes e gêneros textuais orais e escritos" (Brasil, 2009, p. 4).

Ante tais considerações, propomo-nos a analisar o tratamento dado pelas três versões da BNCC (Brasil, 2015, 2016, 2017) ao ensino da escrita alfabética e às práticas de leitura, compreensão e produção de textos escritos na educação infantil. Tantos anos após a publicação dos RCNEI e das DCN, respectivamente, perguntamo-nos: $\mathrm{O}$ que podemos e devemos esperar de uma base curricular nacional para as crianças com menos de 6 anos em nosso país, no que refere à língua escrita e a sua notação?

\section{METODOLOGIA}

O estudo foi desenvolvido com base em análise documental, considerando documento o resultado das escolhas e intenções da sociedade que o produziu em determinado contexto histórico (Le Goff, 1990). Como é habitual, a análise de documentos envolveu a descrição ou transcrição, ordenação e seleção das informações neles contidas (Laville e Dionne, 1999), implicando, portanto, a transformação de um documento primário (bruto) em um documento secundário (Bardin, 1979).

A análise dos dados gerados na pesquisa documental foi desenvolvida por meio da análise temática de conteúdo, contemplando as etapas indicadas por Bardin (1979): pré-análise, análise do material (codificação e categorização da informação), tratamento dos resultados, inferência e interpretação. Nesse processo, no qual foram considerados não apenas os conteúdos explícitos nos documentos, mas também 
os implícitos, as categorias foram construídas adotando o modelo misto (Laville e Dionne, 1999): algumas foram definidas a priori, enquanto outras foram construídas e reconstruídas ao longo do processo de tratamento dos dados.

A análise (documental e de conteúdo) envolveu as três versões da BNCC divulgadas pelo MEC em agosto de 2015, maio de 2016 e, após o golpe que depôs a então presidenta, em dezembro de 2017. Em setembro de 2017, o MEC apresentou uma proposta final da BNCC, ainda não aprovada pelo CNE. Em dezembro do mesmo ano, o documento foi homologado, com algumas reformulações não debatidas publicamente. Nesta pesquisa, consideramos como fonte de dados a versão final, imposta pelo CNE no final daquele ano.

No tratamento dos dados, investigamos as seguintes categorias e subcategorias:

- o ensino da escrita alfabética (estímulo à escrita espontânea, promoção da consciência fonológica, conhecimentos de letras);

- o ensino de leitura (gêneros textuais sugeridos, modalidades de leitura praticadas, habilidades de compreensão leitora);

- o ensino de produção de textos escritos (gêneros textuais sugeridos; modalidades de escrita praticadas - tendo o adulto como escriba ou escrita espontânea de textos pela criança; habilidades de produção de textos).

A categorização foi feita por dois juízes independentes e, em caso de desacordo, um terceiro juiz era acionado. O percentual de concordância superou $90 \%$ em todos os três documentos analisados. Em cada versão da $\mathrm{BNCC}$ foram selecionados e transcritos todos os enunciados que remetiam às categorias adotadas.

\section{ANÁLISE DOS RESULTADOS}

A educação infantil, desde a primeira versão da BNCC, adotou, em lugar de conteúdos ou áreas disciplinares, "campos de experiência" caracterizados como "[...] um arranjo curricular que acolhe as situações e as experiências concretas da vida cotidiana das crianças e seus saberes, entrelaçando-os aos conhecimentos que fazem parte do patrimônio cultural" (Brasil, 2017, p. 38). Assim como Morais (2015), entendemos que esse tipo de organização curricular, também presente em documentos curriculares de outros países, pode ter contribuído, em todas as versões da BNCC, para a indefinição de direitos de aprendizagem com relação a saberes que são responsabilidade de a escola ensinar.

Os campos de experiência definidos na primeira versão do documento eram cinco: "O eu, o outro e o nós"; "Corpo, gestos e movimentos"; "Escuta, fala, pensamento e imaginação"; "Traços, sons, cores e imagens"; "Espaços, tempos, quantidades, relações e transformações". Salientamos que nessa primeira versão da BNCC não havia qualquer delimitação de faixa etária, a não ser a indicação geral de que seriam preservadas as especificidades das crianças até os 6 anos.

A primeira versão do documento afirma a construção de uma suposta nova concepção na educação infantil, com o objetivo de romper com os modos "assisten- 
cialista" e "escolarizante", pois o primeiro desconsideraria a particularidade educativa das crianças na faixa etária de 0 a 5 anos, enquanto o segundo se orientaria equivocadamente por práticas do ensino fundamental (Brasil, 2015). Tal como Morais (2015), consideramos que a segunda perspectiva revela preconceito com o ensino fundamental e atesta uma visão paradisíaca da educação infantil, tratada como o reino da livre expressão e ludicidade, em oposição ao terrorismo que caracterizaria aprender no ensino fundamental. Como observa Moss (2011), essa perspectiva revela um completo distanciamento entre essas duas etapas da escolarização, configurando-se como fonte de suspeita e tensão.

A segunda versão da BNCC foi uma extensão da primeira e investiu mais em explanar sobre a relação da BNCC com as diretrizes curriculares da educação infantil, abordando cinco aspectos: "Princípios da Educação Infantil" (éticos, políticos e estéticos); "Cuidar e educar"; "Interações e brincadeiras"; "Seleção de práticas, saberes e conhecimentos"; e "Centralidade das crianças" (Brasil, 2016). Conforme essa versão da BNCC, o currículo poderia ser organizado com base nos conteúdos das experiências das crianças, destacando as interações por meio de brincadeiras como fundamentais na construção de seres humanos. Como veremos, tal carta de boas intenções mantém uma série de lacunas quando pensamos no direito das crianças de conviverem com a língua escrita e dela se apropriarem antes do ensino fundamental.

Nessa segunda versão, o documento manteve a proposta de "campos de experiências" como organizadores do currículo da educação infantil. Os campos eleitos eram os seguintes: "O eu, o outro e o nós"; “Corpo, gestos e movimentos"; "Traços, sons, cores e imagens"; "Escuta, fala, linguagem e imaginação"; "Espaços, tempos, quantidades, relações e transformações". Nessa versão, os objetivos de aprendizagem e desenvolvimento eram organizados em três subgrupos etários: bebês ( $0-1$ ano e 6 meses), crianças bem pequenas ( 1 ano e 7 meses a 3 anos e 11 meses) e crianças pequenas ( 4 anos a 6 anos e 2 meses). Nesse sentido, houve maior cuidado com a progressão das aprendizagens ou formas de desenvolvimento a serem alcançadas.

A última versão, imposta em 2017, faz uma breve introdução sobre a trajetória da educação infantil, seu reconhecimento e sua implementação na BNCC. Segundo essa versão, a educação infantil seria o início e o fundamento do processo educacional. As creches e pré-escolas teriam o objetivo de ampliar o universo de experiências, conhecimentos e habilidades das crianças, diversificando e consolidando novas aprendizagens. Assim, a prática do diálogo e o compartilhamento de responsabilidades entre a instituição de educação infantil e a família seriam essenciais no desenvolvimento das crianças (Brasil, 2017).

Nessa última versão, a organização curricular por "campos de experiências" foi mantida, e os campos definidos foram os seguintes: "O eu, o outro e o nós"; "Corpo, gestos e movimentos"; "Traços, sons, cores e formas"; "Escuta, fala, pensamento e imaginação"; "Espaços, tempos, quantidades, relações e transformações". Nessa versão, os objetivos de aprendizagem e desenvolvimento são organizados em torno dos mesmos três subgrupos etários da segunda versão, diferenciando-se apenas quanto ao intervalo de idades das "crianças pequenas", que agora passou a ser de 4 anos a 5 anos e 11 meses. 
Nas próximas seções, analisaremos o que as três versões da BNCC (Brasil, 2015,2016 ,2017) por nós selecionadas propõem para o ensino da notação alfabética e das práticas de leitura e produção de textos escritos na educação infantil.

\section{APRENDIZAGEM DA NOTAÇÃO ALFABÉTICA E PRÁTICAS DE LEITURA E ESCRITA NA EDUCAÇÃO INFANTIL: UMA ANÁLISE DAS TRÊS VERSÕES DA BNCC}

O campo de experiência "Escuta, fala, pensamento e imaginação", que é o que nos interessa mais diretamente neste artigo, foi assim denominado na primeira e terceira versões. Na segunda versão, sua nomenclatura foi alterada para "Escuta, fala, linguagem e imaginação". A título de esclarecimento, é importante situar que, em uma das versões da BNCC que chegou a circular por ocasião das audiências públicas, o campo de experiência em tela teve a nomenclatura alterada para "Oralidade e escrita", o que suscitou grande resistência por parte daqueles que parecem querer apagar a língua escrita no currículo da educação infantil.

Observa-se, assim, nas três versões, um evidente interesse de invisibilizar a língua escrita no título desse campo de conhecimento, privilegiando a linguagem oral (escuta, fala) ou a linguagem, de modo geral, sem delimitação, desconsiderando, por um lado, a relevância e a centralidade da cultura escrita em nossa sociedade e, por outro, o interesse, a curiosidade e as hipóteses que as crianças revelam, desde cedo, sobre esse objeto cultural que é a escrita. Como já observava Kramer (2010, p. 121-122), há quase uma década, "[...] o trabalho com a leitura e a escrita segue sendo tabu no Brasil entre os pesquisadores da Educação Infantil”. Esse quadro de realidade parece ter tido visível impacto na BNCC, na qual a leitura e a escrita nessa etapa da escolarização são tratadas, muitas vezes, como temas quase proibidos, conforme analisaremos a seguir.

\section{A APRENDIZAGEM DA NOTAÇÃO ALFABÉTICA}

Na primeira versão da BNCC, no campo de experiências "Escuta, fala, pensamento e imaginação", aparecia muito brevemente, em dois objetivos de aprendizagem, menções a aspectos talvez relacionados ao aprendizado da escrita alfabética: a exploração de rimas em gêneros textuais como parlendas, poesias, canções e a elaboração de primeiras escritas não convencionais ou convencionais. Contudo, além de trazer uma redação pouco clara e de diluir esses aspectos em meio a outros, o documento não fazia nenhuma menção à promoção da consciência fonológica ou ao conhecimento de letras:

Explorar gestos, expressões corporais, sons da língua, rimas, além dos significados e dos sentidos das palavras, nas falas, nas parlendas, nas poesias, canções, livros de histórias e outros gêneros textuais, aumentando gradativamente sua compreensão da linguagem verbal (EIEFPOAO03). (Brasil, 2015, p. 24, grifos nossos) 
Participar ativamente de rodas de conversa, de relatos de experiências, de contação de histórias, elaborando narrativas e suas primeiras escritas não convencionais ou convencionais, desenvolvendo seu pensamento, sua imaginação e as formas de expressá-los (EIEFPOA004). (Brasil, 2015, p. 24, grifos nossos)

Já na segunda versão da BNCC, que, conforme dissemos, estabelecia objetivos de aprendizagem organizados em subgrupos etários, eram mencionadas, além da criação de rimas - estranha e exclusivamente para crianças "bem pequenas" (de 1 ano e 7 meses a 3 anos e 11 meses) - e do registro ou produção de escritas convencionais ou não convencionais - a compreensão de que a escrita é uma representação da fala —, ambas as habilidades apenas para crianças "pequenas" (de 4 anos a 5 anos e 11 meses), conforme indicado no Quadro 1. Nesse sentido, parece haver, pelo menos, o reconhecimento de que ao final da educação infantil a criança deveria descobrir que a escrita registra o som das palavras e não o objeto ou ser a que ela se refere, conforme sugerido por Soares (2011). Apesar disso, essa segunda versão do documento também não mencionava o desenvolvimento da consciência fonológica, nem o conhecimento de letras. É de estranhar também que a criação de rimas - em contexto de brincadeira - destine-se somente a crianças bem pequenas, isto é, aquelas com menos de 4 anos.

Quadro 1 - Objetivos de aprendizagem propostos na segunda versão da Base Nacional Comum Curricular que apresentam alguma relação com o eixo apropriação da notação alfabética, por campo de experiência e subgrupo etário.

\begin{tabular}{|l|l|l|}
\hline \multicolumn{1}{|c|}{$\begin{array}{c}\text { Campo de } \\
\text { experiência }\end{array}$} & $\begin{array}{c}\text { Crianças bem pequenas } \\
\text { (1 ano e 7 meses a 3 anos e } \\
11 \text { meses) }\end{array}$ & \multicolumn{1}{c|}{$\begin{array}{c}\text { Crianças pequenas } \\
\text { (4 anos a 6 anos } \\
\text { e 11 meses) }\end{array}$} \\
\hline $\begin{array}{l}\text { Escuta, fala, } \\
\text { linguagem e } \\
\text { imaginação. }\end{array}$ & $\begin{array}{l}\text { Criar sons, rimas e gestos em } \\
\text { brincadeiras de roda e outras } \\
\text { brincadeiras (EIBPEF02). }\end{array}$ & $\begin{array}{l}\text { Registrar experiências pessoais ou } \\
\text { atividades realizadas na escola em } \\
\text { fotografias, vídeos, desenhos e escrita } \\
\text { (convencional ou não) (EICPEF01). } \\
\text { Produzir suas próprias escritas, } \\
\text { convencionais ou não, em situações } \\
\text { com função social significativa } \\
\text { (EICPEFO4). } \\
\text { Levantar hipóteses sobre textos } \\
\text { escritos, sobre as características da } \\
\text { escrita, frases, palavras, espaços em } \\
\text { branco, sinais de pontuação e outras } \\
\text { marcas, compreendendo que a escrita é } \\
\text { uma representação da fala (EICPEF05). }\end{array}$ \\
\hline $\begin{array}{l}\text { Espaços, tempos, } \\
\text { quantidades, relações } \\
\text { e transformaçôes. }\end{array}$ & $\begin{array}{l}\text { Registrar o que observou ou mediu, } \\
\text { fazendo uso mais elaborado } \\
\text { da linguagem, do desenho, da } \\
\text { matemática, da escrita, ainda que de } \\
\text { forma não convencional, ou utilizando } \\
\text { recursos tecnológicos (EICPET03). }\end{array}$ \\
\hline
\end{tabular}

Fonte: Brasil (2016, p. 75, 81, grifos nossos). 
Finalmente, na terceira versão imposta pelo MEC, vemos que na análise do campo de experiências "Escuta, fala, pensamento e imaginação" também foi possível identificar algo relacionado ao aprendizado da escrita alfabética nas mesmas duas faixas etárias da versão anterior, conforme apresentado no Quadro 2.

Quadro 2 - Objetivos de aprendizagem propostos na terceira versão da Base Nacional Comum Curricular que apresentam alguma relação com o eixo didático Apropriação da notação alfabética, por campo de experiência e subgrupo etário.

\begin{tabular}{|c|c|c|}
\hline $\begin{array}{l}\text { Campo de } \\
\text { experiência }\end{array}$ & $\begin{array}{c}\text { Crianças bem pequenas } \\
\text { (1 ano e } 7 \text { meses a } 3 \text { anos e } \\
11 \text { meses) }\end{array}$ & $\begin{array}{l}\text { Crianças pequenas } \\
\text { (4 anos a } 5 \text { anos } \\
\text { e } 11 \text { meses) }\end{array}$ \\
\hline $\begin{array}{l}\text { Escuta, fala, } \\
\text { linguagem e } \\
\text { imaginação. }\end{array}$ & $\begin{array}{l}\text { Identificar e criar diferentes sons } \\
\text { e reconhecer rimas e aliteraçôes em } \\
\text { cantigas de roda e textos poéticos } \\
\text { (EI02EF02). } \\
\text { Demonstrar interesse e atenção } \\
\text { ao ouvir a leitura de histórias e } \\
\text { outros textos, diferenciando escrita } \\
\text { de ilustrações, e acompanhando, com } \\
\text { orientação do adulto-leitor, a direção } \\
\text { da leitura (de cima para baixo, da } \\
\text { esquerda para a direita) (EI02EF03). } \\
\text { Manusear diferentes instrumentos } \\
\text { e suportes de escrita para desenhar, } \\
\text { traçar letras e outros sinais gráficos } \\
\text { (EI02EF09). }\end{array}$ & $\begin{array}{l}\text { Expressar ideias, desejos e sentimentos } \\
\text { sobre suas vivências, por meio da } \\
\text { linguagem oral e escrita (escrita } \\
\text { espontânea), de fotos, desenhos e outras } \\
\text { formas de expressão (EI03EF01). } \\
\text { Inventar brincadeiras cantadas, } \\
\text { poemas e canções, criando rimas, } \\
\text { aliteraçôes e ritmos (EI03EF02). } \\
\text { Escolher e folhear livros, procurando } \\
\text { orientar-se por temas e ilustrações e } \\
\text { tentando identificar palavras conhecidas. } \\
\text { Produzir suas próprias histórias } \\
\text { orais e escritas (escrita espontânea), } \\
\text { em situações com função social } \\
\text { significativa (EI03EF06). } \\
\text { Levantar hipóteses em relação à } \\
\text { linguagem escrita, realizando registros } \\
\text { de palavras e textos, por meio de escrita } \\
\text { espontânea (EI03EF09). }\end{array}$ \\
\hline $\begin{array}{l}\text { Espaços, tempos, } \\
\text { quantidades, relações } \\
\text { e transformações. }\end{array}$ & & $\begin{array}{l}\text { Registrar observações, manipulações e } \\
\text { medidas, usando múltiplas linguagens } \\
\text { (desenho, registro por números ou } \\
\text { escrita, espontânea, em diferentes } \\
\text { suportes (EICPET03). }\end{array}$ \\
\hline
\end{tabular}

Fonte: Brasil (2017, p. 47-49, grifos nossos).

Nessa terceira versão, encontramos, no caso das crianças pequenas, a indicação de reconhecimento de rimas e aliterações em cantigas de roda e textos poéticos, a diferenciação da escrita de ilustrações e o acompanhamento da direção da escrita, em situações de escuta da leitura de histórias e de outros textos, além do traçado de letras e de outros sinais gráficos a partir do manuseio de diferentes instrumentos e suportes de escrita. No caso das crianças pequenas, menciona-se, além da escrita espontânea (expressão que substitui "escritas convencionais e não convencionais" usada nas versões anteriores), a criação de rimas e aliterações e a tentativa de iden- 
tificação de palavras conhecidas em situações de manuseio de livros. Percebe-se, assim, uma ampliação da menção a aspectos relacionados à aprendizagem da notação alfabética, assim como certa progressão na exploração de rimas e aliterações, tendo em vista que, na terceira versão, indicam-se o reconhecimento de rimas e aliterações para crianças bem pequenas e a criação de rimas e aliterações para crianças pequenas, enquanto na segunda versão era proposta apenas a criação de rimas para as primeiras. No entanto, curiosamente, o traçado de letras não é referido no caso das crianças a partir de 4 anos.

Há, ainda, outro aspecto que chama atenção, quando comparamos a segunda e a terceira versões: trata-se do apagamento da menção relativa à compreensão de que a escrita é uma representação da fala, no caso das crianças pequenas. Desse modo, observa-se um recuo quanto à definição anterior, e esse recuo tem implicações preocupantes, sobretudo quando consideramos as crianças pobres e com menor convivência com a escrita, que tendem a concluir a educação infantil com menos conhecimentos sobre a língua escrita e sua notação que as crianças de grupos economicamente favorecidos. Como observa Soares (2011), embora a educação infantil não tenha como função alfabetizar a criança, ela deve garantir, pelo menos, que a criança descubra o princípio alfabético, isto é, compreenda que a escrita representa o som das palavras e não o objeto ou ser a que se refere.

Como conclusão, fica evidente que em nenhuma das versões da BNCC assumiu-se como tarefa da escola de educação infantil promover, mais explicitamente, uma reflexão sobre a notação alfabética. Não encontramos nenhuma proposta de promoção sistemática de habilidades de consciência fonológica - que não se confunde com treino fonêmico - , fundamentais para a compreensão do sistema alfabético, nem de exploração de letras. Tampouco há qualquer menção à escrita e à análise de palavras estáveis, como os nomes próprios das crianças, atividades bem difundidas nas salas de aula de crianças pequenas, depois da divulgação da teoria da psicogênese da escrita (Ferreiro e Teberosky, 1979).

Brandão e Leal (2013), em estudo no qual analisaram nove propostas curriculares oficiais de capitais do país, perceberam, ao investigar as orientações relativas aos eixos de alfabetização e letramento destinadas ao trabalho com crianças menores de 6 anos, a predominância da perspectiva de alfabetizar letrando entre os documentos analisados (cinco dos nove). Salientaram, porém, a quase total ausência de referências à necessidade de as crianças refletirem sobre os segmentos sonoros das palavras. Além disso, diferentemente da BNCC, todos os documentos por elas investigados, com exceção de um, propuseram a leitura e a escrita dos nomes das crianças, e quatro desses documentos indicaram a formação de repertório de outras palavras estáveis e a identificação/reconhecimento de letras como objeto de ensino.

Em outros países, como França e Portugal, a compreensão do princípio alfabético é assumida como meta nacional em currículos da educação infantil (France-Men, 2015; Portugal, 2016). Nesses dois documentos reguladores, encontramos um grande investimento em prescrever, antes do ensino fundamental, o ensino de habilidades de consciência fonológica, bem como de exploração de palavras escritas, sem que se confunda tal iniciação com um ensino sistemático de relações grafema-fonema e fonema-grafema. 


\section{PRÁTICAS DE LEITURA E COMPREENSÃO DE TEXTOS}

Na primeira versão da BNCC, no campo de experiências "Corpo, gestos e movimento", encontrava-se em um dos objetivos de aprendizagem algo redigido de forma ambígua, talvez envolvendo o ensino de uma habilidade de leitura, tendo em vista que não fica claro se as histórias que a criança recontaria teriam ou não sido lidas por um adulto:

Brincar, utilizando criativamente práticas corporais para realizar jogos e brincadeiras e para criar e representar personagens no faz-de-conta, no reconto de histórias, em danças e dramatizações (EICGMOAO02). (Brasil, 2015, p. 23, grifos nossos)

No campo de experiências "Escuta, fala, pensamento e imaginação" dessa primeira versão, também não havia, em nenhum dos objetivos de aprendizagem, o registro da escuta de leitura de histórias e de outros gêneros de texto. Em vez disso, privilegiava-se no objetivo de aprendizagem EIEFPOA004 a participação em situações como rodas de conversa, relatos de experiência e contação - e não leitura - de histórias. Nessa versão, encontrava-se apenas um objetivo de aprendizagem (EIEFPOA003) que talvez envolvesse o ensino de uma habilidade de leitura, que é a de explorar os significados e sentidos de palavras em parlendas, poesias, canções, livros de histórias e outros gêneros textuais. Pode-se dizer, assim, que não havia, nessa primeira versão, nenhuma proposição explícita relativa à leitura de textos pelo adulto e à escuta pela criança, nem no que concerne à conversa sobre textos lidos.

Já na segunda versão da BNCC, o documento explicitava, entre os "direitos de aprendizagem" do campo "Escuta, fala, pensamento e imaginação", "Participar de rodas de conversa, de relatos de experiências, de contação e leitura de histórias e poesias [...]" (Brasil, 2016, p. 74). Porém, na delimitação dos "objetivos de aprendizagem", não se explicitava, na maior parte das vezes, se as histórias escutadas ou relatadas deveriam ser lidas ou apenas contadas (são usadas expressões como "escuta de pequenas histórias", "histórias que ouve"e "escuta e reconto de histórias"), conforme pode ser observado no Quadro 3. Na verdade, a leitura de histórias é mencionada claramente apenas no objetivo EIBEEF03, que se refere apenas à imitação das variações de entonação e gestos realizados pelos adultos, ao ler histórias e ao cantar. No objetivo EIBPEF03, a escuta de leitura está subentendida, pois se propõe que a criança relate, de modo expressivo, histórias de livros, entre outras coisas.

$\mathrm{Na}$ última versão do documento aqui analisada, no campo de experiências "Escuta, fala, linguagem e imaginação", percebe-se inicialmente uma ampliação de objetivos de aprendizagem e desenvolvimento que mencionam aspectos relacionados ao eixo leitura e compreensão de textos, conforme podemos observar no Quadro 4. Além disso, a quase completa omissão de referências à leitura realizada pelo adulto e à escuta pela criança da leitura desses textos, observada nas versões anteriores, não se manteve nessa última versão, tendo em vista que encontramos agora expressões como "ouvir a leitura de poemas", "ouvir histórias lidas", "ouvir a leitura de histórias e outros textos", "ler histórias" e "leitura de um adulto e/ou para sua própria leitura". 
Quadro 3 - Objetivos de aprendizagem propostos na segunda versão da Base Nacional Comum Curricular que apresentam alguma relação com o eixo práticas de leitura e compreensão de textos, por campo de experiência e subgrupo etário.

\begin{tabular}{|l|l|l|l|}
\hline \multicolumn{1}{c|}{$\begin{array}{c}\text { Campo de } \\
\text { experiência }\end{array}$} & \multicolumn{1}{|c|}{$\begin{array}{c}\text { Bebês } \\
\text { (0-1 ano e 6 } \\
\text { meses) }\end{array}$} & $\begin{array}{c}\text { Crianças bem } \\
\text { pequenas } \\
\text { (1 ano e 7 meses } \\
\text { a 3 anos e 11 } \\
\text { meses) }\end{array}$ & $\begin{array}{c}\text { Crianças } \\
\text { pequenas } \\
\text { (4 anos a 6 anos e } \\
\text { 2 meses) }\end{array}$ \\
\hline $\begin{array}{l}\text { Escuta, fala, } \\
\text { pensamento e } \\
\text { imaginação. }\end{array}$ & $\begin{array}{l}\text { Apreciar a escuta de } \\
\text { pequenas histórias } \\
\text { (EIBEEF02). } \\
\text { Imitar as variações de } \\
\text { entonação e gestos } \\
\text { realizados pelos adultos, } \\
\text { ao ler histórias e ao cantar } \\
\text { (EIBEEF03). }\end{array}$ & $\begin{array}{l}\text { Relatar de modo } \\
\text { expressivo, experiências } \\
\text { e fatos acontecidos, } \\
\text { histórias de livros, } \\
\text { filmes ou peças teatrais } \\
\text { (EIBPEF03). } \\
\text { Criar novos elementos } \\
\text { para as histórias que ouve } \\
\text { (EIBPEF04). }\end{array}$ & $\begin{array}{l}\text { Inventar enredos para } \\
\text { brincadeiras, histórias, } \\
\text { poemas, canções, roteiros } \\
\text { de vídeos e encenações } \\
\text { definindo os contextos } \\
\text { e os personagens } \\
\text { (EICPEF02). }\end{array}$ \\
\hline $\begin{array}{l}\text { Corpo, gestos e } \\
\text { movimentos. }\end{array}$ & & $\begin{array}{l}\text { Recriar danças, cenas de } \\
\text { teatro, histórias, músicas } \\
\text { (EIBPTS05). }\end{array}$ & $\begin{array}{l}\text { Demonstrar controle e } \\
\text { adequação do uso de seu } \\
\text { corpo na participação } \\
\text { em momentos de } \\
\text { cuidado, brincadeiras } \\
\text { e jogos, escuta e reconto } \\
\text { de histórias, atividades } \\
\text { artísticas, dentre } \\
\text { outras possibilidades } \\
\text { (EICPCG03). }\end{array}$ \\
\hline $\begin{array}{l}\text { Traços, sons, } \\
\text { formas e imagens. }\end{array}$ & & & \\
\hline
\end{tabular}

Fonte: Brasil (2016, p. 72, 75, 78, grifos nossos).

Ainda sobre a última versão, percebe-se também, no caso da faixa etária das crianças de 4 anos a 5 anos e 11 meses, a inclusão de dois outros aspectos: o levantamento de hipóteses sobre gêneros textuais mediante estratégias de leitura e a seleção de livros e textos conhecidos para leitura pela própria criança. Já para a faixa etária de 1 ano e 7 meses a 3 anos e 11 meses, observa-se uma menção à formulação e resposta de perguntas sobre fatos de história narrada, embora não se explicite se a história deveria ser lida ou contada.

Ainda que alguns objetivos indicados no Quadro 4 não se relacionem diretamente a habilidades de compreensão de leitura (EI01EF07, EI01EF09, EI02EF07, EI02EF08), os incluímos porque remetem a dispositivos de apropriação sociocultural de gêneros escritos com que a criança convive(rá), relacionando-se, portanto, à faceta sociocultural da língua escrita (usos, funções e valores atribuídos à escrita em diferentes contextos), que compõe, com a faceta interativa (interação 
Quadro 4-Objetivos de aprendizagem e desenvolvimento propostos na terceira versão da $\mathrm{BNCC}$ que apresentam alguma relação com o eixo apropriação da notação alfabética, por campo de experiência e subgrupo etário.

\begin{tabular}{|c|c|c|c|}
\hline $\begin{array}{l}\text { Campo de } \\
\text { experiência }\end{array}$ & $\begin{array}{c}\text { Bebês } \\
\text { (0-1 ano } \\
\text { e } 6 \text { meses) }\end{array}$ & $\begin{array}{c}\text { Crianças bem } \\
\text { pequenas } \\
\text { (1 ano e } 7 \text { meses a } 3 \\
\text { anos e } 11 \text { meses) }\end{array}$ & $\begin{array}{c}\text { Crianças } \\
\text { pequenas } \\
\text { (4 anos a } 5 \text { anos } \\
\text { e } 11 \text { meses) }\end{array}$ \\
\hline $\begin{array}{l}\text { Escuta, fala, } \\
\text { linguagem e } \\
\text { imaginação. }\end{array}$ & $\begin{array}{l}\text { Demonstrar interesse ao } \\
\text { ouvir a leitura de poemas e } \\
\text { a apresentação de músicas } \\
\text { (EI01EF02). } \\
\text { Demonstrar interesse ao ouvir } \\
\text { bistórias lidas ou contadas, } \\
\text { observando ilustrações e os } \\
\text { movimentos de leitura do adulto- } \\
\text { leitor (modo de segurar o } \\
\text { portador e de virar as páginas) } \\
\text { (EI01EF03). } \\
\text { Reconhecer elementos das } \\
\text { ilustrações de histórias, } \\
\text { apontando-os a pedido do } \\
\text { adulto-leitor (EI01EF04). } \\
\text { Imitar as variações de } \\
\text { entonação e gestos realizados } \\
\text { pelos adultos ao ler histórias e } \\
\text { ao cantar (EI01EF05). } \\
\text { Conhecer e manipular } \\
\text { materiais impressos e } \\
\text { audiovisuais em diferentes } \\
\text { portadores (livro, revista, gibi, } \\
\text { jornal, cartaz, CD, tablet, etc.) } \\
\text { (EI01EF07). } \\
\text { Participar de situações de } \\
\text { escuta de textos em diferentes } \\
\text { gêneros textuais (poemas, } \\
\text { fábulas, contos, receitas, } \\
\text { quadrinhos, anúncios etc.) } \\
\text { (EI01EF08). } \\
\text { Conhecer e manipular } \\
\text { diferentes instrumentos e } \\
\text { suportes de escrita (EI01EF09). }\end{array}$ & $\begin{array}{l}\text { Demonstrar interesse e } \\
\text { atenção ao ouvir a leitura } \\
\text { de histórias e outros textos, } \\
\text { diferenciando escrita de } \\
\text { ilustrações, e acompanhando, } \\
\text { com orientação do adulto- } \\
\text { leitor, a direção da leitura (de } \\
\text { cima para baixo, da esquerda } \\
\text { para a direita). (EI02EF03). } \\
\text { Formular e responder perguntas } \\
\text { sobre fatos da história narrada, } \\
\text { identificando cenários, } \\
\text { personagens e principais } \\
\text { acontecimentos (EI02EF04). } \\
\text { Relatar experiências e fatos } \\
\text { acontecidos, histórias ouvidas, } \\
\text { filmes ou peças teatrais } \\
\text { assistidos (EI02EF05). } \\
\text { Manusear diferentes } \\
\text { portadores textuais } \\
\text { demonstrando reconhecer } \\
\text { seus usos sociais (EI02EF07). } \\
\text { Manipular textos eparticipar } \\
\text { de situações de escuta para } \\
\text { ampliar seu contato com } \\
\text { diferentes gêneros textuais } \\
\text { (parlendas, histórias de } \\
\text { aventura, tirinhas, cartazes de } \\
\text { sala, cardápios, notícias etc.) } \\
\text { (EI02EF08). }\end{array}$ & $\begin{array}{l}\text { Levantar hipóteses } \\
\text { sobre gêneros } \\
\text { textuais veiculados } \\
\text { em portadores } \\
\text { conhecidos, } \\
\text { recorrendo a } \\
\text { estratégias de } \\
\text { observação gráfica } \\
\text { e/ou de leitura } \\
\text { (EI03EF07). } \\
\text { Selecionar livros e } \\
\text { textos de gêneros } \\
\text { conhecidos para } \\
\text { a leitura de um } \\
\text { adulto elou para } \\
\text { sua própria leitura } \\
\text { (partindo de seu } \\
\text { repertório sobre } \\
\text { esses textos, como } \\
\text { a recuperação } \\
\text { pela memória, } \\
\text { pela leitura das } \\
\text { ilustrações etc.) } \\
\text { (EI03EF08). }\end{array}$ \\
\hline
\end{tabular}

Fonte: Brasil (2017, p. 47-48, grifos nossos).

entre as pessoas e expressão e compreensão de mensagens por meio da escrita), o letramento (Soares, 2016).

Quanto aos gêneros e portadores textuais com que as crianças deveriam conviver na educação infantil, o Quadro 5 sintetiza esses dados distribuindo os gêneros e portadores por versão da $\mathrm{BNCC}$ e faixa etária das crianças.

Assim, foi possível identificar na primeira versão da BNCC apenas alguns gêneros da tradição oral, quando se mencionava a exploração de parlendas, poesias, 
Quadro 5-Gêneros e portadores textuais propostos nas três versões da Base Nacional Comum Curricular por subgrupo etário.

\begin{tabular}{|c|c|c|c|}
\hline Versão & Faixa Etária & Portadores Textuais & Gêneros Textuais \\
\hline $1^{\mathrm{a}}$ & $0-6$ meses & Livros de histórias & $\begin{array}{c}\text { Parlendas, poesias, canções e outros } \\
\text { gêneros textuais }\end{array}$ \\
\hline \multirow{3}{*}{$2^{\mathrm{a}}$} & $\begin{array}{c}\text { Bebês ( } 0-1 \text { ano e } 6 \\
\text { meses) }\end{array}$ & & Histórias \\
\hline & $\begin{array}{c}\text { Crianças bem } \\
\text { pequenas }(1 \text { ano e } \\
7 \text { meses a } 3 \text { anos e } \\
11 \text { meses })\end{array}$ & & Histórias \\
\hline & $\begin{array}{c}\text { Crianças pequenas } \\
(4 \text { anos a } 6 \text { anos e } 2 \\
\text { meses })\end{array}$ & & $\begin{array}{l}\text { Histórias, poemas, canções, roteiros } \\
\text { de vídeos e de encenações }\end{array}$ \\
\hline \multirow{3}{*}{$3^{\mathrm{a}}$} & $\begin{array}{c}\text { Bebês } \\
(0 \text { ano a } 1 \text { e } 6 \\
\text { meses })\end{array}$ & $\begin{array}{l}\text { Livro, revista, gibi, jornal, } \\
\quad \text { cartaz, CD, tablet }\end{array}$ & $\begin{array}{l}\text { Poemas, histórias, fábulas, contos, } \\
\text { receitas, quadrinhos, anúncios }\end{array}$ \\
\hline & $\begin{array}{c}\text { Crianças bem } \\
\text { pequenas } \\
\text { (1 ano e } 7 \text { meses a } \\
3 \text { anos e } 11 \text { meses })\end{array}$ & Cartazes de sala & $\begin{array}{c}\text { Cantigas de roda e textos poéticos, } \\
\text { histórias, parlendas, histórias } \\
\text { de aventura, tirinhas, cardápios, } \\
\text { notícias }\end{array}$ \\
\hline & $\begin{array}{l}\text { Crianças pequenas } \\
(4 \text { anos a } 5 \text { anos e } \\
11 \text { meses })\end{array}$ & Livro & Poemas, canções e histórias \\
\hline
\end{tabular}

Fonte: Brasil (2015, 2016, 2017).

canções, além de livros de histórias. Na segunda versão, além de histórias — único gênero mencionado nos objetivos para bebês e para crianças bem pequenas -, apareciam poemas, canções, roteiros de vídeos e de encenações, citados nos objetivos para crianças pequenas. Nessa segunda versão da BNCC, eram também mencionados nos "direitos de aprendizagem" os seguintes gêneros, sem delimitação de subgrupo etário: parlendas, trava-línguas, adivinhas, histórias, poesias e canções.

Entre a primeira e a segunda versão não houve uma grande disparidade quanto aos gêneros a serem trabalhados. $\mathrm{Na}$ terceira versão da $\mathrm{BNCC}$, os gêneros textuais prescritos para as três faixas etárias incluíam mais diversidade: poemas, histórias, fábulas, contos, receitas, quadrinhos, anúncios, parlendas, tirinhas, cardápios, entre outros, o que também ocorria no caso dos portadores de textos: livros, revistas, gibis, jornais, cartazes, CDs e tablets. Uma primeira evidência a ser comentada é a não progressão do universo de portadores e gêneros textuais a serem explorados, especialmente quando se vê o que foi prescrito para as crianças bem pequenas. Chama atenção, especialmente na terceira versão, a redução dos portadores e gêneros textuais indicados ao longo dos três subgrupos etários, sobretudo quando comparamos aqueles prescritos para as crianças pequenas (4 anos a 6 anos e 2 meses) com os destinados aos bebês ( $0-1$ ano e 6 meses) e às crianças bem pequenas ( 1 ano e 7 meses a 3 anos e 11 meses). 
Apesar da ampliação em relação à versão de 2015, não há, em 2017, nenhuma menção aos gêneros textuais escritos nos campos de experiência: "O eu, o outro e o nós"; "Corpo, gestos e movimentos"; "Traços, sonhos e formas"; "Espaços, tempos, quantidades, relações e transformações". Apenas aparecem no campo de experiências "Escuta, fala, pensamento e imaginação", o que pode dar a entender que, ao explorar temáticas ligadas, por exemplo, ao mundo natural ou à sociedade, as crianças não deveriam escutar a leitura de textos escritos ou manusear portadores de textos (impressos ou digitais) que tratassem daqueles temas.

\section{PRÁTICAS DE ESCRITA DE TEXTOS}

Na primeira versão da $\mathrm{BNCC}$, não havia menção à atuação do professor como escriba na produção de textos escritos e se mencionava vagamente a elaboração de narrativas e de escritas não convencionais ou convencionais, conforme transcrito a seguir. Não havia, porém, explicitação clara de que as tais narrativas seriam registradas por escrito ou apenas oralizadas.

Participar ativamente de rodas de conversa, de relatos de experiências, de contação de histórias, elaborando narrativas e suas primeiras escritas não convencionais ou convencionais, desenvolvendo seu pensamento, sua imaginação e as formas de expressá-los (EIEFPOA004). (Brasil, 2015, p. 25, grifos nossos)

Já na segunda versão apareceram no campo "Escuta, fala, pensamento e imaginação", conforme pode ser observado no Quadro 6, objetivos que mencionavam a escrita de textos claramente ou, pelo menos, de modo subtendido: registrar experiências pessoais ou atividades realizadas na escola usando escrita (convencional ou não); ditar textos orais ao/à professor/a; produzir escritas, convencionais ou não, em situações com função social significativa. Como vemos, houve uma mudança radical em relação à primeira versão, na qual as experiências de escrita de textos não eram explicitamente enfocadas.

Finalmente, na terceira versão, é possível notar a presença da produção de gêneros textuais escritos de modo muito mais explícito, conforme indicado também no Quadro 6: expressar ideias, desejos e sentimentos por meio da linguagem escrita (escrita espontânea); recontar histórias ouvidas para registro escrito pelo professor; produzir histórias escritas (escrita espontânea); registrar textos usando a escrita espontânea.

Percebe-se, assim, uma mudança significativa na terceira versão, ao se evidenciar mais claramente situações de produção escrita de textos pelas próprias crianças por meio de escrita espontânea e de produção de textos escritos (apenas de histórias), tendo o professor como escriba. Porém tais objetivos são indicados tanto na segunda quanto na terceira versão, apenas para crianças de 4 a 5 anos e 7 meses - antes disso não há nenhuma indicação quanto à produção escrita de textos, embora saibamos que desde cedo as crianças são capazes de produzir textos escritos, ainda que não consigam escrevê-los de modo convencional, tal como evidenciado, por exemplo, nos clássicos estudos de Rego (1988) e de Mayrink-Sabinson (1998). 
Quadro 6- Objetivos de aprendizagem propostos na segunda e terceiras versões da Base Nacional Comum Curricular que apresentam alguma relação com o eixo produção de textos escritos, por campo de experiência e subgrupo etário.

\begin{tabular}{|c|c|c|}
\hline \multirow{2}{*}{$\begin{array}{c}\text { Campo de } \\
\text { experiência }\end{array}$} & \multicolumn{2}{|c|}{ Crianças pequenas ( 4 anos a 6 anos e 2 meses) } \\
\hline & $2^{\mathrm{a}}$ versão & $3^{\mathrm{a}}$ versão \\
\hline $\begin{array}{l}\text { Escuta, fala, } \\
\text { linguagem e } \\
\text { pensamento ( } 2^{\text {a }} \\
\text { versão). } \\
\text { Escuta, fala, } \\
\text { pensamento e } \\
\text { imaginação ( } 3^{\text {a }} \\
\text { versão). }\end{array}$ & $\begin{array}{l}\text { Registrar experiências pessoais ou } \\
\text { atividades realizadas na escola em } \\
\text { fotografias, vídeos, desenhos e escrita } \\
\text { (convencional ou não) (EICPEF01). } \\
\text { Inventar enredos para brincadeiras, } \\
\text { histórias, poemas, canções, roteiros } \\
\text { de vídeos e de encenações, definindo } \\
\text { os contextos e os personagens } \\
\text { (EICPEF02). } \\
\text { Ditar textos orais ao/à professor/a, } \\
\text { individualmente ou em grupo } \\
\text { (EICPEF03). } \\
\text { Produzir suas próprias escritas, } \\
\text { convencionais ou não, em situações } \\
\text { com função social significativa } \\
\text { (EICPEF04). }\end{array}$ & $\begin{array}{l}\text { Expressar ideias, desejos e sentimentos sobre } \\
\text { suas vivências, por meio da linguagem } \\
\text { oral e escrita (escrita espontânea), de fotos, } \\
\text { desenhos e outras formas de expressão } \\
\text { (EI03EF01). } \\
\text { Recontar histórias ouvidas para produção } \\
\text { de reconto escrito, tendo o professor como } \\
\text { escriba (EI03EF05). } \\
\text { Produzir suas próprias histórias orais } \\
\text { e escritas (escrita espontânea), em } \\
\text { situações com função social significativa } \\
\text { (EI03EF06). } \\
\text { Levantar hipóteses em relação à linguagem } \\
\text { escrita, realizando registros de palavras } \\
\text { e textos, por meio de escrita espontânea } \\
\text { (EI03EF09). }\end{array}$ \\
\hline
\end{tabular}

Fonte: Brasil (2015, p. 75; 2016, p. 47-48, grifos nossos).

Parece-nos também que o tom aligeirado com que tais objetivos são formulados (por exemplo, "registros de palavras e textos") revela o quanto não encontramos um tratamento mais cuidadoso do direito ao aprendizado da escrita de gêneros textuais na educação infantil, considerando, inclusive, a diversidade de propriedades linguísticas dos gêneros com que as crianças pequenas conviveriam na escola e fora dela. Afinal, cedo tais crianças podem compreender e aprender que a linguagem de um bilhete é diferente daquela própria de uma receita ou de uma história (Rego, 1988).

\section{CONSIDERAÇÕES FINAIS}

O exame das três versões da BNCC revela oscilações quanto ao que se prescreve e ao que se omite quanto ao ensino da notação alfabética e das práticas de leitura e de produção e textos escritos. Além de certa aleatoriedade, constata-se, por vezes, falta de clareza e de progressão na definição dos objetivos a serem alcançados, quando o tema é a apropriação da linguagem escrita e da notação alfabética. Atesta-se, assim, o tabu ainda vigente e denunciado por Kramer (2010), já há algum tempo, quando se cogita a possibilidade de a língua escrita fazer parte dos direitos de aprendizagem das crianças que frequentam a educação infantil.

Considerando as três versões do documento analisadas, podemos concluir, sem dúvida, o quanto ainda estamos longe de assegurar a nossas crianças - em especial as de meio popular - o direito de, na educação infantil, serem ajudadas a compreender como nosso sistema alfabético funciona. Isso se torna ainda mais grave se levarmos em conta que a versão da BNCC aprovada pelo CNE, em 2017, reduziu o ensino 
formal de alfabetização a apenas dois anos, no início do ensino fundamental, e que no texto curricular relativo a essa etapa também existem oscilações e incoerências entre o discurso sociointeracionista de ensino de língua assumido e a visão da notação escrita como mero código de transcrição de sons (Garcia-Reis e Godoy, 2018). Nesse caso, a versão final da BNCC parece reduzir a apropriação do sistema alfabético a um aprendizado de associações entre fonemas e grafemas e busca diferenciá-lo da "ortografização", como se nos dois primeiros anos do ensino fundamental as crianças não estivessem também incorporando regras da norma ortográfica de nossa língua.

Sim, entendemos que a opção por não alfabetizar na educação infantil não precisa nem deve ser confundida com uma sonegação do direito das crianças com menos de 6 anos a conviver com palavras escritas e sobre elas refletir. Interpretamos que a omissão de nossa BNCC a esse respeito é um fator de perpetuação de desigualdades sociais, ajudando a manter o apartheid educacional que caracteriza nosso país (Morais, 2012). Diferentes pesquisas atestam o quanto a maioria das crianças que entram em nossas salas de aula de primeiro ano do ensino fundamental, nas redes públicas, têm ainda hipóteses pré-silábicas de escrita. Isto é, começam a alfabetização formal sem compreender, ainda, que a escrita nota os segmentos sonoros das palavras, em flagrante desvantagem em relação a seus pares de classe média.

Encontramos na segunda e terceira versões da Base uma mais clara prescrição a respeito das práticas de leitura de textos a serem vivenciadas com os alunos da educação infantil e alguns objetivos - especialmente na última versão - relativos à produção de textos escritos. Julgamos, porém, que um currículo nacional precisa ser bem mais explícito quanto ao repertório de gêneros textuais com que as crianças progressivamente se deveriam familiarizar, tanto na creche quanto na pré-escola.

$\mathrm{Na}$ mesma direção, entendemos que seria muito mais produtivo se tal documento explicitasse, de forma cristalina, as habilidades de compreensão leitora a serem ensinadas antes da alfabetização formal, visto que há bastante tempo já sabemos quanto o precoce desenvolvimento de tais habilidades, mediante a escuta de textos lidos pelo adulto, reduz o fracasso em compreensão de leitura (Fontes e Cardoso-Martins, 2004). O mesmo pode ser dito sobre a escrita de textos: há pelo menos três décadas, dispomos de evidências de que uma criança pode apropriar-se das características de gêneros como histórias, notícias e receitas, antes de poder ler e escrever sozinha e convencionalmente (Rego, 1988). Que ganho haveria em nosso currículo nacional não assumir tais conhecimentos como direito de aprendizagem de todas as crianças, independentemente de sua origem sociocultural?

O tabu em relação ao ensino e à aprendizagem da língua escrita na educação infantil teria feito com que nossa BNCC, em sua segunda e terceira versões, assumisse uma perspectiva de defesa de algum letramento para nossas crianças pequenas, mas pouco ou nenhum direito assegurado de avançarem na compreensão do sistema alfabético, especialmente quando consideramos a supressão, na terceira versão do documento, do objetivo que mencionava a compreensão de que a escrita é uma representação do som das palavras. Esse mesmo tipo de viés foi constatado por Brandão e Leal (2013), ao examinarem as propostas curriculares de nove capitais de diferentes regiões de nosso país.

$\mathrm{Na}$ contramão de tais preconceitos, encontramos, felizmente, propostas curriculares municipais, como a de Lagoa Santa, em Minas Gerais, que contempla, desde 
a educação infantil, um cuidadoso trabalho que articula as práticas sociais de leitura e escrita de textos e a apropriação da escrita alfabética (Morais, 2018; Soares, 2014). Morais (2018), ao analisar diferentes versões daquele documento — entre 2008 e 2017 —, assinala o quanto cada edição sua revela um esforço de negociação coletiva guiada por um espírito republicano e com um grau de explicitação - de metas, habilidades, gêneros textuais etc. - incomparavelmente mais coerente e superior àquele proposto na BNCC. Apesar do curto prazo de existência da proposta, que desde 2007 vem construída coletivamente pelos educadores daquela cidade, sob a coordenação de Magda Soares, os resultados tornaram-se evidentes: a porcentagem de alunos do terceiro ano daquela rede municipal com nível de proficiência recomendado aumentou de 33,9\%, em 2006, para 84,9\%, em 2012, conforme dados do Programa de Avaliação da Alfabetização (Proalfa), realizado pelo estado de Minas Gerais (Soares, 2014, p. 171-172).

Desse modo, seria um retrocesso "adaptar" aquela proposta municipal (Lagoa Santa, 2017) ao que dita a BNCC aprovada pelo CNE sem qualquer debate público. Bases curriculares nacionais, estaduais e municipais? Sim, as queremos. Mas que sejam fruto de debate democrático e sério e contemplem o direito das crianças de, desde a educação infantil, ampliarem progressivamente seus conhecimentos sobre a língua escrita e sobre sua notação.

\section{REFERÊNCIAS}

AGUIAR, M. A. Política educacional e a Base Nacional Comum Curricular: o processo de formulação em questão. Currículo sem Fronteiras, [S.l.], v. 18, n. 3, p. 722-738, set./dez.2018. Disponível em: http://www.curriculosemfronteiras.org/vol18iss3articles/ aguiar.pdf. Acesso em: 8 fev. 2019.

BARDIN, L. Análise de conteúdo. Tradução Luís Antero Reta e Augusto Pinheiro. Lisboa: Edições 70, 1979.

BRANDÃO, A. C. P. A.; LEAL, T. F. Propostas curriculares para a educação infantil: orientações sobre a alfabetização e o letramento das crianças. In: NOGUEIRA, A. L. H. (org.). Ler e escrever na infância: imaginação, linguagem e práticas culturais. Campinas: Leitura Crítica, 2013. p. 137-159.

BRANDÃO, A. C. P.; LEAL, T. F. Alfabetizar e letrar na educação infantil: o que isso significa? In: BRANDÃO, A. C. P.; ROSA, E. C. S. (org.). Ler e escrever na educação infantil: discutindo práticas pedagógicas. Belo Horizonte: Autêntica, 2010. p. 13-31. BRANDÃO, A.C.P.; SILVA, A. O ensino da leitura e escrita e o livro didático na educação infantil. Revista Educação, Porto Alegre,v. 40, n. 3, p. 440-449, set./dez.2017. Disponível em: http://revistaseletronicas.pucrs.br/ojs/index.php/faced/article/view/23852/16544. Acesso em: 20 dez. 2018. http://dx.doi.org/10.15448/1981-2582.2017.3.23852

BRASIL. Referencial Curricular Nacional para a Educação Infantil. Brasília, DF: MEC, 1998.

BRASIL. Lei n. 11.274, de 6 de fevereiro de 2006. Altera a redação dos artigos 29, 30 e 87 da lei n. 9.394, de 20 de dezembro de 1996, que estabelece as diretrizes e bases da educação nacional, dispondo sobre a duração de 9 (nove) anos para o ensino 
fundamental, com matrícula obrigatória a partir dos 6 (seis) anos de idade. Diário Oficial da União, Brasília, DF, 7 fev. 2006. Disponível em: http://www.planalto.gov. br/ccivil_03/_Ato2004-2006/2006/Lei/L11274.htm. Acesso em: 24 fev. 2019.

BRASIL. Resolução n. 5, de 11 de dezembro de 2009. Fixa as Diretrizes Curriculares Nacionais para a Educação Infantil. Diário Oficial da União: seção 1, Brasília, DF, p. 1-5, 18 dez. 2009. Disponível em: http://portal.mec.gov.br/index.php?option=com_ docman\&view=download\&alias=3749-resolucao-denei-dez-2009\&category_ slug=fevereiro-2010-pdf\&Itemid=30192. Acesso em: 20 mar. 2020.

BRASIL. Lei n. 12.796, de 4 de abril de 2013. Altera a lei n. 9.394, de 20 de dezembro de 1996, que estabelece as diretrizes e bases da educação nacional, para dispor sobre a formação dos profissionais da educação e dar outras providências. Diário Oficial da União, Brasília, DF, 5 abr. 2013. Disponível em: http://www.planalto.gov.br/ccivil_03/_ Ato2011-2014/2013/Lei/L12796.htm. Acesso em: 22 fev. 2019.

BRASIL. Base Nacional Comum Curricular. Brasília, DF: MEC, 2015. Disponível em: http://historiadabncc.mec.gov.br/documentos/BNCC-APRESENTACAO.pdf. Acesso em: 20 out. 2015.

BRASIL. Base Nacional Comum Curricular. Brasília, DF: MEC, 2016. Disponível em: http://historiadabncc.mec.gov.br/documentos/bncc-2versao.revista.pdf. Acesso em: 12 maio 2016.

BRASIL. Base Nacional Comum Curricular. Brasília, DF: MEC, 2017. Disponível em: http://portal.mec.gov.br/index.php?option=com_docman\&view=download\&alias=79611anexo-texto-bncc-aprovado-em-15-12-17-pdf\&category_slug=dezembro-2017pdf\&Itemid=30192. Acesso em: 1 mar. 2018.

CAMPOS, M.M. et al. A contribuição da educação infantil de qualidade e seus impactos no início do ensino fundamental. Educação e Pesquisa, São Paulo, v. 37, n. 1, p. 15-33, jan./abr. 2011. https://doi.org/10.1590/S1517-97022011000100002

CERTEAU, M. A invenção do cotidiano - artes de fazer. Petrópolis: Vozes, 1994.

CRUZ, M. S.; ALBUQUERQUE, E. B. Alfabetização e letramento no $1^{\circ}$ ciclo: o que as crianças aprendem sobre a escrita a cada ano? Revista Brasileira de Estudos Pedagógicos, Brasília, v. 92, n. p. 126-147, jan./abr. 2011. http://dx.doi. org/10.24109/2176-6681.rbep.92i230.558

FERREIRO, E.; TEBEROSKY, A. Los sistemas de escritura en el desarrollo del niño. México: Siglo XXI, 1979.

FONTES, M. J. O.; CARDOSO-MARTINS, C. Efeitos da leitura de histórias no desenvolvimento da linguagem de crianças de nível sócio-econômico baixo. Psicologia: Reflexão e Crítica, v. 17, n. 1, p. 83-94, 2004. https://doi.org/10.1590/ S0102-79722004000100011

FORQUIN, J.-C. Escola e cultura: as bases sociais e epistemológica do conhecimento escolar. Tradução Guacira Lopes Louro. Porto Alegre: Artes Médicas, 1993.

FRANCE. Ministere de L'Education Nationale.Au BO spécial du 26 mars 2015: Programme de L'École Maternelle. Paris: 2015. Disponível em: http://www.education.gouv.fr/cid87300/ rentree-2015-le-nouveau-programme-de-1-ecole-maternelle.html. Acesso em: 4 maio 2015. 
GARCIA-REIS, A. R.; GODOY, A. R. G. L. O ensino de leitura nos anos iniciais do ensino fundamental: a proposta da Base Nacional Comum Curricular. Currículo sem Fronteiras, [S.l.], v. 18, n. 3, p. 1.025-1.043, set./dez. 2018.

KRAMER, S. O papel da educação infantil na formação do leitor: descompassos entre as políticas, as práticas e a produção acadêmica. In: FRADE, I. C. A. S. et. al. (org.). Convergências e tensões no campo da formação e do trabalho docente. Belo Horizonte: Autêntica, 2010. p. 111-133.

LAGOA SANTA (Município). Secretaria de Educação. Projeto Alfaletrar: metas em progressão. Lagoa Santa: Secretaria Municipal de Educação, 2017.

LAVILLE, C.; DIONNE, J. A construção do saber: manual de metodologia da pesquisa e ciências humanas. Tradução de Heloísa Monteiro e Francisco Settinere. Porto Alegre: Artmed, 1999.

LE GOFF, J. História e memória. Tradução de Bernardo Leitão et al. Campinas: UNICAMP, 1990.

LEITE, C. Currículo, didática e formação de professores: algumas ideias conclusivas. In: OLIVEIRA, M. R. N. S.; PACHECO, J. A. (org.). Currículo, didática e formação de professores. Campinas: Papirus, 2013. p. 193-207.

LOPES, A. C.; MACEDO, E. Teorias de currículo. São Paulo: Cortez, 2011.

MAYRINK-SABINSON, M. L. T. Reflexões sobre o processo de aquisição da escrita. In: ROJO, R. (org.). Alfabetização e letramento: perspectivas linguísticas. Campinas: Mercado de Letras, 1998.

MORAIS, A. G. Refletindo sobre o documento introdutório dos PCNs. In: MARCUSCHI, E.; SOARES, E. A. L. (org.). Avaliação educacional e currículo. Recife: Editora Universitária, 1997.v. 1, p. 155-165.

MORAIS, A. G. Sistema de escrita alfabética. São Paulo: Melhoramentos, 2012.

MORAIS, A. G. Base Nacional Comum Curricular: que direitos de aprendizagem defendemos para as crianças na educação infantil? Revista Brasileira de Alfabetização, Vitória, v. 1, n. 2, p. 161-173, jul./dez. 2015.

MORAIS, A. G. A republicana proposta curricular de língua portuguesa que Magda Soares vem construindo com os educadores de Lagoa Santa - MG: coerência e inovação. Práxis Educativa, Ponta Grossa, v. 13, n. 3, p. 857-877, set./dez. 2018. https://doi. org/10.5212/PraxEduc.v.13i3.0013

MORAIS, A. G.; LEAL, T. F.; PESSOA, A. C. G. O ensino da língua portuguesa no ciclo de alfabetização e sua avaliação pela Provinha Brasil. In: INSTITUTO NACIONAL DE ESTUDOS E PESQUISAS EDUCACIONAIS ANÍSIO TEIXEIRA. Avaliações da educação básica em debate: ensino e matrizes de referências das avaliações em larga escala. Brasília, DF: INEP, 2013. p. 153-174.

MOSS, P. Qual o futuro da relação entre educação infantil e ensino obrigatório? Cadernos de Pesquisa, São Paulo, v. 41, n. 142, p. 142-159, jan./abr. 2011. Disponível em: http://www.scielo.br/pdf/cp/v41n142/v41n142a08.pdf Acesso em: 15 fev. 2019. 
OLIVEIRA, S. A. Progressão das atividades de língua portuguesa e o tratamento dado à heterogeneidade das aprendizagens: um estudo da prática docente no contexto dos ciclos. 2010. 446 f. Tese (Doutorado em Educação) — Universidade Federal de Pernambuco, Recife, 2010.

PORTUGAL. Ministério da Educação. Direção Geral da Educação. Orientações Curriculares para a Educação Pré-Escolar. Lisboa: Portugal, 2016.

REGO, L. L. B. Descobrindo a língua escrita antes de aprender a ler: algumas implicações pedagógicas. In: KATO, M. (org.). A concepção de escrita pela criança. Campinas: Pontes Editores, 1988.p. 105-134.

SOARES, M. Alfabetização e letramento na educação infantil. Revista Pátio Educação Infantil, Porto Alegre, ano VII, n. 20, p. 6-9, jul./out. 2009.

SOARES, M. Aprendizagem lúdica. [Entrevista concedida a] Rubem Barros. Revista Educação, São Paulo, 1 nov. 2011. Disponível em: http://www.revistaeducacao.com. br/aprendizagem-ludica/. Acesso em: 15 nov. 2018.

SOARES, M. “Não existe um currículo no Brasil”. Revista Presença Pedagógica, Belo Horizonte, v. 18, n. 107, p. 5-13, 2012.

SOARES, M. Formação de rede: uma alternativa de desenvolvimento profissional de alfabetizadores/as. Cadernos CENPEC, São Paulo, v. 4, n. 2, p. 146-173, dez. 2014. http://dx.doi.org/10.18676/cadernoscenpec.v4i2.294

SOARES, M. Alfabetização: a questão dos métodos. São Paulo: Contexto, 2016.

\section{SOBRE OS AUTORES}

Artur Gomes de Morais é doutor em psicologia pela Universidad de Barcelona (Espanha). Professor da Universidade Federal de Pernambuco (UFPE).

E-mail: agmorais59@gmail.com

Alexsandro da Silva é doutor em educação pela Universidade Federal de Pernambuco (UFPE). Professor da mesma instituição.

E-mail: alexs-silva@uol.com.br

Gabryella Silva do Nascimento é graduanda em pedagogia pela Universidade Federal de Pernambuco (UFPE).

E-mail: gabryellasilva.2010@gmail.com

Recebido em 12 de março de 2019

Aprovado em 22 de novembro de 2019 